\title{
Interleukin 4 Co-Stimulates the PDGF-BB-and bFGF-Mediated Proliferation of Mesangial Cells and Myofibroblasts
}

\author{
M. Sommer U. Eismann J.Gerth G. Stein \\ Department of Internal Medicine IV, Friedrich Schiller University, J ena, Germany
}

\section{Key Words}

Interleukin 4 - Endothelial cells · Myofibroblasts . Mesangial cells · Tubular epithelial cells · Proliferation . Growth factors

\begin{abstract}
Background: Although many mediators involved in the pathogenesis of fibrosis are known, its precise mechanism is still unknown. In vitro experiments may contribute to the recognition of cellular changes which also take place during fibrosis. Methods: Renal tubular epithelial cells (EPC), mesangial cells (MC) and glomerular endothelial cells (GEDC) as well as endothelial cells (EDC) and myofibroblasts (MF) from cattle were isolated to measure the proliferation and protein synthesis in the presence of individual and combined cytokines/growth factors in cell cultures. Results: Cytokines stimulating or permitting the proliferation of myofibroblast-like cells (MFLC) (MC and MF), caused damage of endothelial cells (EDC, GEDC), whereas EPC were stable. The proliferation of MFLC was strongly stimulated by PDGF-BB and bFGF and elevated more than twofold in the presence of interleukin 4 (IL-4), but IL-4 alone had no effect. Furthermore,
\end{abstract}

Reprint requests to Günter Stein, MD, Department of Internal Medicine IV, University of J ena, Erlanger Allee 101, D-07740 J ena (Germany).

\begin{tabular}{ll}
\hline KARGER & ( 2002 S. Karger AG, Basel \\
Fax +41613061234 & \\
$\begin{array}{l}\text { E-Mail karger@karger.ch } \\
\text { www.karger.com }\end{array}$ & $\begin{array}{l}\text { Accessible online at: } \\
\text { www.karger.com/journals/nef }\end{array}$
\end{tabular}

the proliferation of transdifferentiated endothelial cells (TEC), obtained by incubation of EDC with TNF $\alpha$ and bFGF, was stimulated with both PDGF-BB/IL-4 and bFGF/ IL-4 in the same way and proved to be stable with respect to TNF $\alpha$. Conclusion: Interleukin 4 co-stimulates the PDGF-BB- and bFGF-mediated proliferation of MC, MF, and TEC. TNF $\alpha$ does not inhibit the proliferation of extracellular matrix-synthesizing cells, but has an inhibitory or even toxic effect on EDC and GEDC. It may be concluded that cytokines released in inflamed renal tissue influence tubulointerstitial cells in different ways, resulting in progressive tissue damage and fibrosis in which the EDC would be the most sensitive cells. Thus, we speculate that microvascular injury in these areas leads to ischemia and malnutrition of tubular EPC and may be responsible for ongoing tubular damage and resulting renal interstitial fibrosis.

Copyright $\odot 2002$ S. Karger AG, Basel

\section{Introduction}

Renal interstitial fibrosis (RIF) and glomerulosclerosis are characterised by an accumulation of extracellular matrix (ECM) after a primary injury, and subsequent inflammation [1-3]. If the primary damage exceeds a certain limit, inflammation persists on a diminished level.

Cytokines and growth factors act on cellular functions and either determine the healing or progression of tissue

\footnotetext{
Prof. Dr. G. Stein

Department of Internal Medicine IV

Friedrich-Schiller-University of Jena

D-07740 Jena (Germany)

Tel. +4903641 939148, Fax +4903641939235, E-Mail guenter.stein@med.uni-jena.de
} 
damage resulting in fibrosis and organ failure. In fibrotic diseases, the affected tissue is unable to regulate the inflammatory process due to the persistence of inflammatory signals [4]. Although there is a growing list of inflammatory mediators [2, 5-7], little is currently known about the manner in which they initiate and sustain the disease. Furthermore, previous results obtained from animal models of RIF indicate that the same cytokines are involved in acute injury and progressive fibrosis $[3,5,8]$.

In animal models of RIF, the focal progression of fibrosis has been proved $[9,10]$. In damaged renal interstitial areas, resident cells (tubular epithelial cells, microvascular endothelial cells, ECM synthesizing myofibroblast-like cells) and invading inflammatory cells (mainly macrophages/monocytes, T-lymphocytes) are involved in cytokine secretion. High local cytokine concentrations may be the cause of disturbed functions of resident cells and possibly of their transdifferentiation [11-13]. The progression of fibrosis is cytokine-dependent and not the result of irreversibly changed autonomous ECM-producing cells as shown from the finding that tubular epithelial cell damage is essential for progressive fibrosis [14].

It has been shown that the action of cytokine combinations differs from the sum of actions of individual cytokines $[15,16]$. Because the reaction of cells from different species to the same cytokine or growth factor may be considerably different, a comparison of cellular reactions should be performed using different cells from the same species. So far, such experiments have not been carried out, because the isolation and cultivation of the renal cells (endothelial cells (EDC), tubular epithelial cells (EPC), and mesangial cells/myofibroblasts $(\mathrm{MC} / \mathrm{MF})$ ) obtained from humans and laboratory animals would be complicated. However, the easy isolation and handling of bovine EDC and tubular EPC will allow such an experiment. Using these cells, we compared the action of cytokines regarding cellular proliferation, protein synthesis and secretion. The results can help to decide which of these mediators or which combinations are essential for progressive fibrosis.

\section{Materials and Methods}

\section{Sources, Abbreviations}

Human growth factors and cytokines were purchased from Sigma (Deisenhofen, Germany), TGF $\beta 1$ and IL-4 were from NatuTec (Frankfurt, Germany). Cell culture medium and supplements were obtained from Biochrom (Berlin, Germany) and other substances were from Sigma.

Interleukin 4 Co-Stimulates Cell

Proliferation
The following abbreviations were used: transforming growth factor- $\beta 1$ (TGF $\beta 1$ ), platelet-derived growth factor-BB (PDGF-BB), basic fibroblast growth factor (bFGF), epidermal growth factor (EGF), vascular endothelial growth factor (VEGF), tumor necrosis factor- $\alpha$ $(\mathrm{TNF} \alpha)$, interleukin $1 \beta$ (IL-1 $\beta$ ), and interleukin 4 (IL-4). The designation of bovine cells was abbreviated as follows: renal tubular epithelial cells, endothelial cells from the lung artery (EDC), glomerular endothelial cells (GEDC), MC, MF, endothelial cell derived myofibroblast-like cells (TEC).

\section{Cell Cultures}

For the isolation of bovine cells, kidneys and lung arteries of adult cattles were obtained from a local slaughterhouse (Jena, Germany). Glomeruli were isolated by the sieving method. Renal cortex was minced and passed through serial sieves (tissue grinder kit; Sigma, Deisenhofen, Germany). For separation glomeruli passing through a $140 \mu \mathrm{m}$ sieve, being hold back on a $104-\mu \mathrm{m}$ sieve. A pure glomerular fraction was obtained by repeated sedimentation. The glomeruli were incubated in the presence of collagenase (Worthington, Freehold, N.J., USA; $216 \mathrm{IU} / \mathrm{mg}, 0.6 \mathrm{mg} / \mathrm{ml}$ ) for $15 \mathrm{~min}$ at $37^{\circ} \mathrm{C}$. After washing twice with PBS, glomerular remnants consisting of $\mathrm{MC}$ and GEDC were suspended at a density of 1,000 remnants/ml in DMEMHam's F-12 [1:1] (D/H) supplemented with 10\% FCS, penicillin/ streptomycin, and $L$-glutamine solution (1:100, Biochrom).

For the isolation of GEDC, the suspension was given onto gelatincoated culture dishes and incubated at $37^{\circ} \mathrm{C}$ in a humidified atmosphere of $5 \% \mathrm{CO}_{2}$ and $95 \%$ air. The medium was changed after 3-5 days, and nonadherent remnants were separated. After outgrowth of endothelial cells was visible in addition to $\mathrm{MC}$, the cell cultures were trypsinized $(0.025 \%$ trypsin, $0.5 \mathrm{~m} M$ EDTA) for a short time at room temperature to mainly detach the GEDC. The washed cells were plated onto gelatin-coated dishes at low density. GDEC fractions were isolated from semiconfluent cultures using cloning cylinders. The studies were performed using GEDC after more than 6 passages.

Bovine MC were obtained from glomerular remnants plated onto culture dishes (without gelatin) at a density of about 200 remnants/ $\mathrm{cm}^{2}$ in $20 \%$ FCS-containing medium. Under these conditions, mainly cultures of preferentially MC were obtained within 2-3 weeks. The culture medium after the first trypsinization was supplemented with $10 \%$ FCS. MC cultures were used for experiments after more than 8 passages.

Bovine tubular epithelial cells (EPC) were isolated from kidney cortex using tissue pieces (approximately 1-3 $\mathrm{mm}^{3}$ ). 10-15 fragments were placed onto the growth surface of $20 \mathrm{~cm}^{2}$ culture dishes, which had been previously coated with collagen isolated from rat tails. The use of coated culture dishes is not essential but makes the detachment of cells, employing trypsin, easier. Outgrowths were obtained within some days. The cells were isolated by trypsinization and cultured in $\mathrm{D} / \mathrm{H}$ medium without FCS but supplemented with insulin/transferrin/sodium selenite (ITS, $\times 100$; Biochrom). Further growth stimulation with EGF $(10 \mathrm{ng} / \mathrm{ml})$ is only slightly effective. For experiments, cell cultures of passages 5-10 were used.

Bovine MF were obtained from lung arteries. Pieces of 2-4 $\mathrm{mm}^{3}$ were cut from the tunica media of the vessels and plated onto culture dishes $\left(20 \mathrm{~cm}^{2}\right)$. The pieces were moistened with FCS. After half an hour at $37^{\circ} \mathrm{C}$, culture medium (D/H containing $\left.10 \% \mathrm{FCS}\right)$ was added. The outgrowths were subcultured and passaged 10 times. Although these MF may be derived from vascular smooth muscle cells, they are similar to other MF, for instance to MC and activated fibroblasts. 
Bovine endothelial cells (EDC) were isolated from lung arteries. 10- to 12-cm long blood vessels were closed on an end with the aid of a clamp and placed into a breaker. Collagenase solution (Worthington, $0.2 \mathrm{mg} / \mathrm{ml} \mathrm{PBS}$ ) were put into the blood vessel. The breaker was placed in a water bath at $37^{\circ} \mathrm{C}$ and incubated for $12 \mathrm{~min}$. Subsequently, the solution was removed, and the cells were separated and washed by centrifugation. A second cell fraction was obtained by desintegration using a higher collagenase concentration $(1 \mathrm{mg} / \mathrm{ml}$; $15 \mathrm{~min}$ ). Cells from both cell fractions were cultured separately in culture dishes with D/H medium supplemented with $10 \%$ FCS. For cell culture experiments passages 10-20 were used.

\section{Cellular Proliferation and Protein Synthesis Induced by \\ Cytokines}

The cells were replated onto multiwell dishes and incubated with suitable concentrations of the mediators in the presence of low amounts of FCS in the culture medium (EPC with $0.5 \%$,others with $1.0 \%$ FCS). To obtain higher differences in the promoting or inhibiting action on cell proliferation or protein synthesis, the cultures were initially preincubated with mediators. After medium change and second mediator application, the tritium-labelled substances (thymidine, leucine, proline) were added, and the cultures were further incubated for at least $14 \mathrm{~h}$. Cell proliferation was determined using the $\left[{ }^{3} \mathrm{H}\right]$ thymidine incorporation. Cells grew to $30-50 \%$ density in $10 \%$ FCS-containing medium and subsequently starved for 1 day in $1 \%$ FCS-containing medium in order to make the cells quiescent. At this point, new medium with or without growth factors/cytokines were added. The concentrations of the mediators were $10 \mathrm{ng} /$ $\mathrm{ml}$, only TGF $\beta 1$ and TNF $\alpha$ had the concentrations of 2 and $6 \mathrm{ng} / \mathrm{ml}$, respectively. After a further $24 \mathrm{~h}$, the medium was changed and fresh medium with or without mediators and $0.6 \mu \mathrm{Ci} /$ well (methyl- ${ }^{3} \mathrm{H}$ )thymidine $(5 \mathrm{Ci} / \mathrm{mmol}$; Amersham Pharmacia, Little Chalfont, England) were added. After a incubation period of $14 \mathrm{~h}$, cell proliferation was arrested by placing the culture plates in a refrigerator at $4{ }^{\circ} \mathrm{C}$. The cells were washed three times using PBS at this temperature, fixed with $10 \%$ trichloroacetic acid (TCA), washed 2 times with 5\% TCA, solubilized with $0.3 \mathrm{M}$ sodium hydroxide containing $1 \%$ SDS, and counted in a liquid scintillation counter (LSC) to measure cellular $\left[{ }^{3} \mathrm{H}\right]$ thymidine incorporation. Cells incubated with control medium were assigned a relative value for $\left[{ }^{3} \mathrm{H}\right]$ thymidine uptake of $100 \%$. Incorporation of thymidine into cells treated with mediators was calculated as percentage of control. Only EPC grew under altered conditions: This medium contained $0.5 \%$ FCS and the incubation times were doubled.

De novo protein synthesis was determined under the same conditions as the thymidine uptake with some differences: The culture medium was supplemented with sodium ascorbate $(50 \mu \mathrm{g} / \mathrm{ml})$ and $\beta$-aminopropionitrile $(80 \mu \mathrm{g} / \mathrm{ml})$. In 24 -well plates, the starved cells were incubated with control medium supplemented with $1 \%$ (EPC with $0.5 \%)$ FCS or with this medium containing growth factors/cytokines. After $24 \mathrm{~h}$, the medium was changed and new medium containing the same mediators, and $0.6 \mu \mathrm{Ci} /$ well $\left[{ }^{3} \mathrm{H}\right]$-labelled leucine (Leu) or proline (Pro) $\left(\mathrm{L}-\left(4,5-{ }^{3} \mathrm{H}\right)\right.$ leucine, $157 \mathrm{Ci} / \mathrm{mmol}, \mathrm{L}-\left(2,3-{ }^{3} \mathrm{H}\right)$ proline, $48 \mathrm{Ci} / \mathrm{mmol}$; Amersham Pharmacia) were added. Pro incorporation into TCA-precipitable protein was used as a marker for collagen synthesis, since Pro is a major component of and is preferentially incorporated in collagen. The uptake of amino acids (AA) was stopped by placing the plates in a refrigerator at $4{ }^{\circ} \mathrm{C}$. For the detection of AA incorporation into secreted proteins, the medium of three or four wells each, containing the same mediator, was removed. Ali- quots were used for the precipitation of proteins. After addition of $10 \mathrm{mg} \mathrm{BSA} / \mathrm{ml}$ medium using a $20 \% \mathrm{BSA}$ solution, proteins were precipitated by $4 \mathrm{ml} \mathrm{10 \%} \mathrm{TCA.} \mathrm{The} \mathrm{precipitates} \mathrm{were} \mathrm{washed} \mathrm{three-}$ fold using $6 \mathrm{ml}$ of $5 \%$ TCA containing $0.5 \mathrm{mM}$ of the respective unlabelled AA. Finally, the protein pellet was solubilized in $0.3 \mathrm{M}$ sodium hydroxide containing $1 \%$ SDS and counted in a liquid scintillation counter.

For determination of the AA uptake in cellular proteins, the cells were washed with ice-cold PBS three times, fixed with $10 \%$ TCA, washed 2 times with 5\% TCA, solubilized with $0.3 \mathrm{M}$ sodium hydroxide containing $1 \%$ SDS, and placed in a liquid scintillation counter to measure the radioactivity, which allowed the calculation of molar amounts of incorporated AA in proteins. The ratio Pro/Leu increases with elevation of the collagen content of proteins and can serve to assess the collagen synthesis induced by cytokines.

\section{Transdifferentiation of Endothelial Cells}

Confluent cultures of endothelial cells (EDC and GEDC) growing in $\mathrm{D} / \mathrm{H}$ medium supplemented with $10 \% \mathrm{FCS}$ were incubated with $\mathrm{TNF} \alpha(1-6 \mathrm{ng} / \mathrm{ml})$ and $\mathrm{bFGF}(10 \mathrm{ng} / \mathrm{ml})$. The medium was changed every third day. The concentrations of TNF $\alpha$ were chosen in dependence of cell viability, so that not more than $10 \%$ of the cells were detached from the surface of the culture dishes. Normally, after 1014 days most cells were transdifferentiated into myofibroblast-like cells that were resistant to TNF $\alpha$ but were growth-stimulated by PDGF-BB, bFGF or their combination with IL-4. The transdifferentiated EDC (TEC) reacted negatively against anti-von Willebrand factor VIII antibodies and positively against anti- $\alpha$-smooth muscle actin ( $\alpha$ SMA) antibodies. To exclude that TEC grew from a very low amount of myofibroblast in endothelial cell cultures, transdifferentiation experiments were performed also with EDC of passages 1723 and the homogeneity of the cultures was checked by immunocytochemistry (anti-factor VIII antibody).

\section{Identity of Cells, Immunocytochemistry}

The identity of the cells were assessed by their shape, growth behavior and reactions induced by cytokines/growth factors. Furthermore, cells were characterized by immunocytochemistry using FITC-labelled secondary antibodies (FITC-conjugated goat antimouse IgG, FITC-conjugated $\mathrm{F}\left(\mathrm{ab}^{\prime}\right)_{2}$ fragment swine antirabbit IgG; Dako, Glostrup, Denmark). Cells were plated onto cover glasses (or in the case of GEDC onto glasses coated with collagen $)(24 \times 24 \mathrm{~mm})$ placed in round culture dishes (Falcon, Plymouth, England). After reaching semi-confluency, they were fixed with ice-cold methanol at $-20^{\circ} \mathrm{C}$ for $8 \mathrm{~min}$ and dried shortly at environmental temperature. The primary antibodies were used to determine the identity of EDC/ GEDC, EPC and myofibroblast-like cells (MFLC = MC, MF, TEC), respectively: rabbit antihuman von Willebrand factor (Dako); antipan cytokeratin monoclonal antibody (MOAB) (Becton Dickinson, Bedford, Mass., USA); antihuman cytokeratin 19 MOAB (Dako); rabbit anti- $\alpha$ SMA (Dako), antihuman vimentin MOAB (Boehringer).

\section{Light Microscopy}

Cultured cells on plastic dishes (Falcon) were fixed with buffered formaldehyde (4\%) and thereafter with $92 \%$ methanol. After drying, cells were stained with $0.05 \%$ Coomassie in $10 \%$ acetic acid containing 25\% methanol and then with Giemsa (Boehringer, Mannheim, Germany). 
Statistical Analysis

Values were expressed as means \pm SD. Statistical analyses were performed using the two-tailed t test. $\mathrm{p}<0.05$ was considered statistically significant. Each experiment was performed as least three times, and single values of cell cultures result from three or four wells.

\section{Results}

There was only a minor effect of the mediators on the proliferation of tubular EPC although in these experiments longer incubation times were used than in those with other cells (fig. 1a). Only EGF and, to a somewhat lesser extent, bFGF stimulated cell proliferation as compared to the control. Moreover, only a relatively high concentration of TNF $\alpha$ was able to inhibit the proliferation of EPC significantly. TGF $\beta 1$ diminished the growth-stimulating effect of EGF. Other mediators were relatively ineffective. The proliferation of EDC was stimulated by bFGF, VEGF and a combination of the two (fig. 1b). A significant growth inhibition was caused by TGF $\beta 1$, IL-4 and TNF $\alpha$ and a combination of these with noninhibitory mediators. Thus, the inhibiting effects of TNF $\alpha$ and IL-4 were not compensated in the presence of $b F G F$ and VEGF. Since the isolation of renal interstitial microvascular EDC is not practicable in a large number of EPC in primary cultures, we cultured glomerular endothelial cells from homogenous glomerular fractions and compared the influence of mediators on the two endothelial cells (EDC and GEDC). Figure $1 \mathrm{~b}$ and $\mathrm{c}$ demonstrates that the same mediators stimulate or inhibit the proliferation of GEDC and EDC.

A different pattern of cell proliferation was found in experiments with MC and MF, summarized as MFLC (fig. 1d, e). In comparison to EDC, GED, and EPC, the proliferation of these cells was stimulated to a much higher extent and only sparsely inhibited by growth factors like TNF $\alpha$ and TGF $\beta 1$. Furthermore, this inhibiting action was overcompensated by PDGF-BB and bFGF. The effect of both growth factors was additive in the absence of other mediators. Remarkably, IL-4 elevated the stimulating action of PDGF-BB and bFGF about twofold, but increased the proliferation itself only slightly. To demonstrate that EDC-derived MFLC (obtained by cytokinemediated transdifferentiation of EDC and termed as TEC), react similarly to other myofibroblasts, we incubated TEC cultures with mediators and found a comparable profile of induction and only an insignificant inhibition (fig. 1f). The bFGF causes a higher cell proliferation than PDGF-BB. Figure 2 shows photomicrographs of confluently growing EPC and endothelial cells (EDC and GEDC and those of MFLC (MC, MF, TEC).
Incubation of the cell cultures with tritium-labelled Leu and Pro was performed to determine protein synthesis. The content of Pro and its secondary modification product hydroxyproline is much higher in collagens than in other proteins [17].

Figure 3a shows that only EGF stimulated the cellular uptake of Pro in EPC significantly, as compared to the controls, whereas TNF $\alpha$ caused a decrease in the uptake of the two AA. In EDC cultures, the hypertrophic effect of TGF $\beta 1$ and the growth-promoting action of bFGF may be responsible for the increased AA uptake, whereas PDGF$\mathrm{BB}$ was ineffective (fig. 3b). The AA uptake in MC, MF, and TED was similar (fig. 3c-e). The differences between the high thymidine uptake and the comparably low AA uptake results from the higher nuclear/cytoplasmic ratio in dividing cells. The ratios of incorporated Pro and Leu in cellular proteins varied only slightly, even in the presence of mediators (table 1). Compared to other cells, EPC revealed the lowest Pro/Leu ratio. Table 1 gives the ratios of the secreted proteins obtained from control cultures as well as the means of the ratios from cultures incubated in the presence of mediators. These ratios differ significantly from those measured in cellular proteins and can be explained by a higher collagen content in secreted proteins than that found in cellular proteins. Figure $4 a, b$ shows the influence of cytokines on the protein secretion of MC and MF in cell culture. PDGF-BB and bFGF caused higher amounts of secreted proteins than TGF $\beta 1$, which is considered to have a strongly stimulating effect on the ECM synthesis under in vivo conditions $[18,19]$.

Table 1. Pro/Leu-ratio in cellular and secreted proteins

\begin{tabular}{lll}
\hline Cells & Cellular protein $^{1}$ & Secreted protein $^{2}$ \\
\hline MC & $0.471 \pm 0.033(8)$ & $0.700 \pm 0.080(4)$ \\
MF & $0.525 \pm 0.075(9)$ & $0.763 \pm 0.073(4)$ \\
TEC & $0.405 \pm 0.007(6)$ & n.d. \\
EDC & $0.384 \pm 0.029(6)$ & $0.591 \pm 0.071(4)$ \\
EPC & $0.202 \pm 0.013(7)$ & $0.266 \pm 0.029(4)$ \\
\hline
\end{tabular}

1 Means \pm SD resulting from cell cultures incubated with different mediators and from controls (see fig. 2).

2 Means \pm SD resulting from cell cultures, incubated with mediators (TGF, PDGF-BB, TGF + PDGF-BB) and from unstimulated control cultures; in the case of EPC, cells were cultured with EGF instead of PDGF-BB; number of independent experiments, each performed in triplicate, is given in parentheses. 
Fig. 1. Effect of growth factors and cytokines on the proliferation $\left({ }^{3} \mathrm{H}\right.$-thymidine incorporation). a Renal tubular epithelial cells (EPC). b Endothelial cells from the lung artery (EDC). c Glomerular endothelial cells (GEDC).

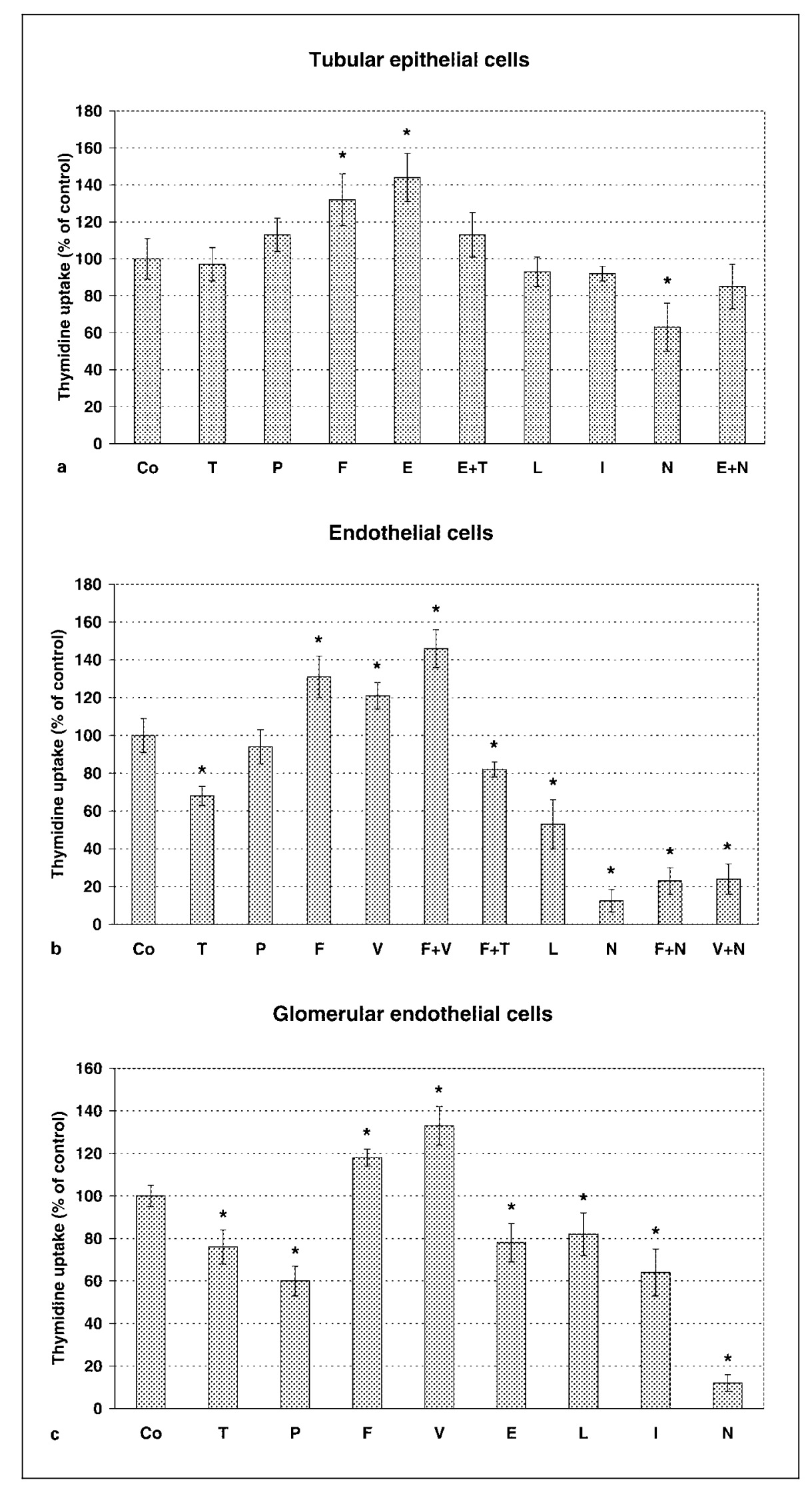


Fig. 1.d Mesangial cells. e Myofibroblasts (MF). f Endothelial cells derived myofibroblast-like cells (TEC). The cells were cultured in 24-well plates with $\mathrm{D} / \mathrm{H}$ medium containing $1 \%$ FCS (in the case of EPC only $0.5 \%$ FCS) and the following mediators: TGF $\beta 1$ (T), PDGF-BB (P), bFGF (F), EGF (E), IL-4 (L), IL-1 $\beta(\mathrm{I}), \mathrm{TNF} \alpha(\mathrm{N}), \mathrm{VEGF}(\mathrm{V})$ (concentration: (T) $2 \mathrm{ng} / \mathrm{ml}$; (N) $6 \mathrm{ng} / \mathrm{ml}$; others 10 $\mathrm{ng} / \mathrm{ml}$ ) for $24 \mathrm{~h}$. After the addition of ${ }^{3} \mathrm{H}$-thymidine, cells were further incubated for at least $14 \mathrm{~h}$. Values are given in percentage of control cultures grown in the absence of mediators. The data represent the means $\pm \mathrm{SD}$ of 3-6 independent experiments each conducted in triplicates or quadruplicates. Statistical significance was analyzed by the two tailed t test. ${ }^{*} \mathrm{p}<0.05$ vs. control, ${ }^{\circ} \mathrm{p}<0.05$ vs. cells incubated with one mediator only.

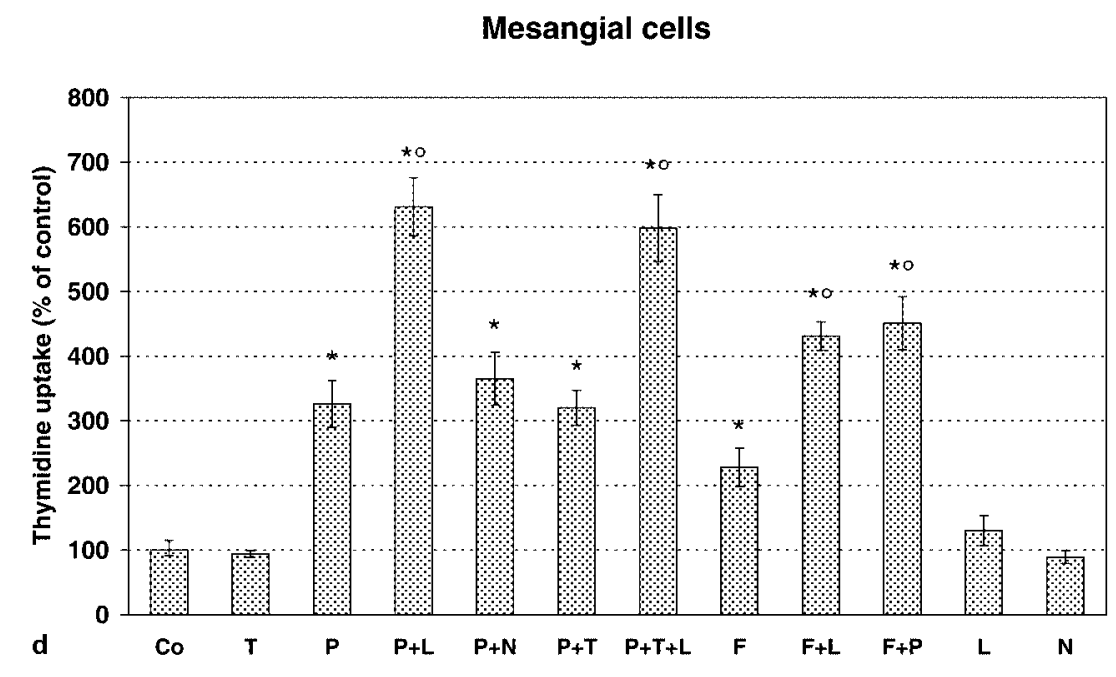

Myofibroblasts

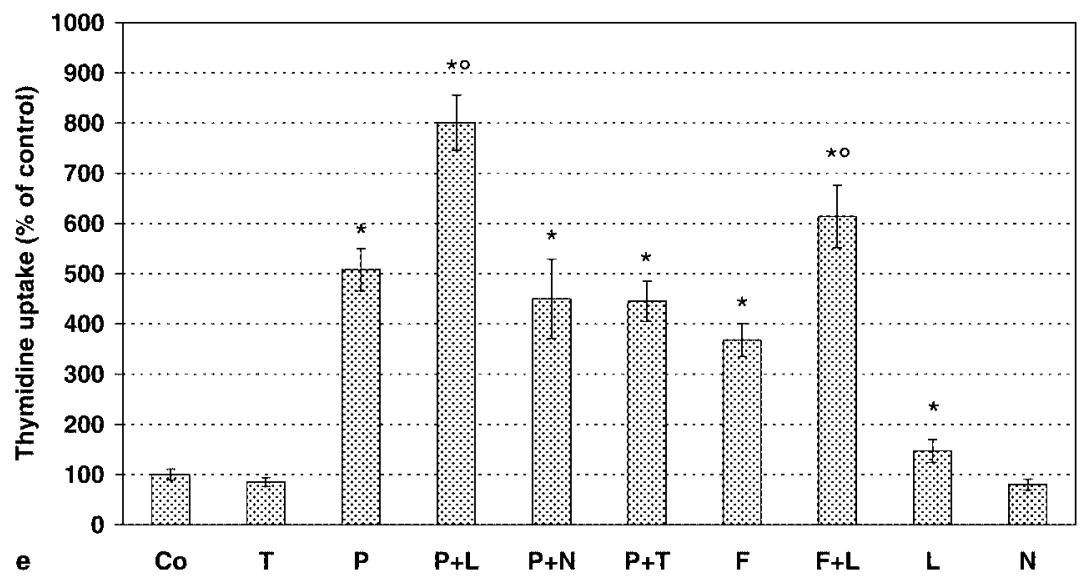

Endothelial cell-derived myofibroblasts

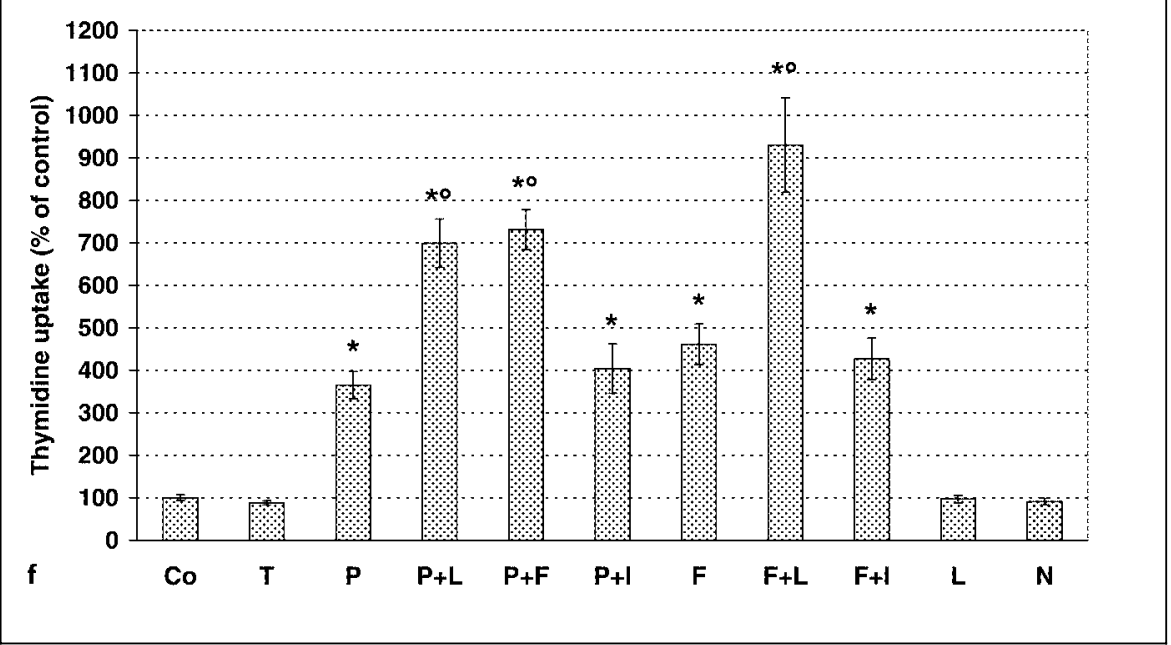

Nephron 2002;92:868-882 

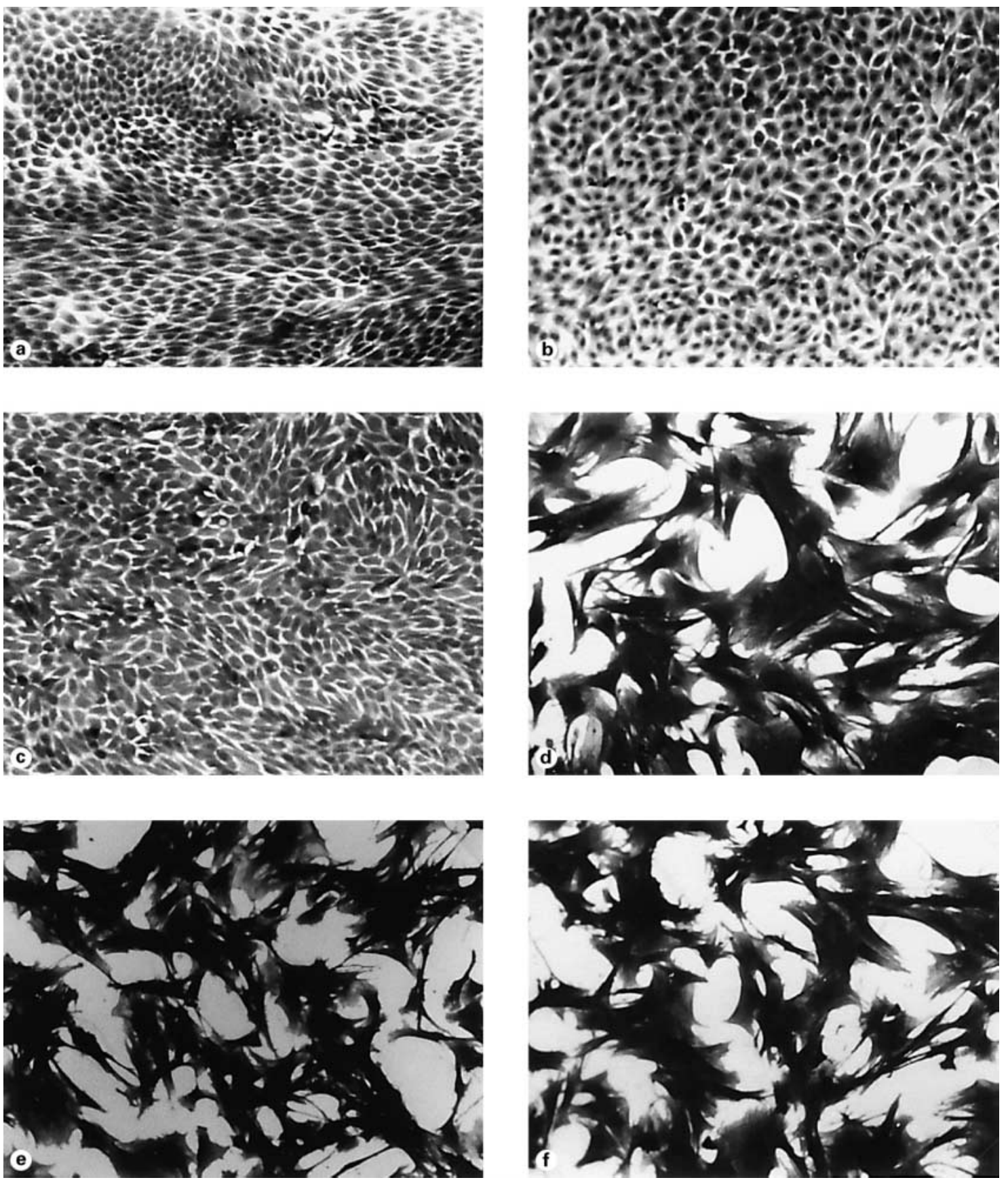

Fig. 2. Light micrographs of bovine cells cultured in $\mathrm{D} / \mathrm{H}$ medium. Fixed cells were stained with Coomassie and after drying with Giemsa. a Renal tubular epithelial cells (EPC). b Endothelial cells from the lung artery (EDC). c Glomerular endothelial cells (GEDC). d Mesangial cells (MC). e Myofibroblasts (MF). f Endothelial-cell-derived myofibroblast-like cells (TEC) obtained by endothelial-mesenchymal transdifferentiation (induced by TNF $\alpha$ and bFGF). While untreated endothelial cells exhibit a cuboidal, cobblestone-like morphology in confluent cultures, the transdifferentiated cells are similar to MC and MF, show an elongated, stellate morphology, grow in multiple layers of cells in confluent cultures, and are comparably large. Original magnification $\times 100$. 
For Fig. 3d and e see next page

Fig. 3. The effects of growth factors and cytokines on the protein synthesis. The synthesis of cellular proteins was assessed by ${ }^{3} \mathrm{H}-P r o-$ (gray columns) and ${ }^{3} \mathrm{H}-\mathrm{Leu}-$ (hatched columns) incorporation in the presence of ascorbic acid and $\beta$-aminopropionitrile. For abbreviations and experimental conditions, see the legend to figure 1 . The data represent the means \pm SD of 3-6 independent experiments each conducted in triplicate or quadruplicate. Values were obtained from wells of the same cultures and expressed in percentage of controls to allow a direct comparison. ${ }^{*} \mathrm{p}<0.05$ versus control. The molar Pro/Leu ratio is depicted above the columns. a Renal tubular epithelial cells. b Endothelial cells from the lung artery. c Mesangial cells.

\section{Epithelial cells}

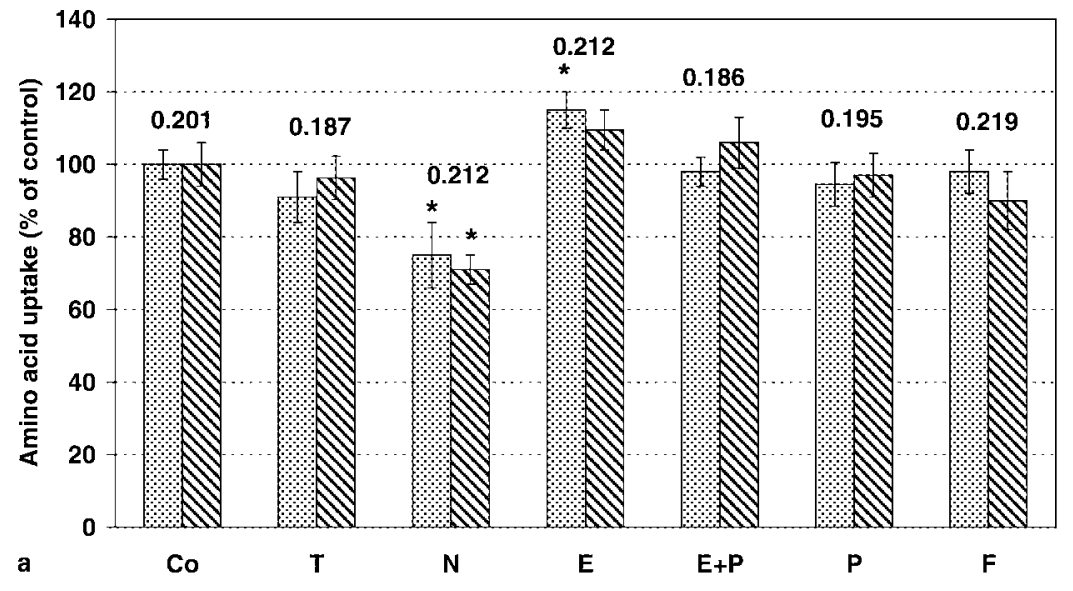

Endothelial cells

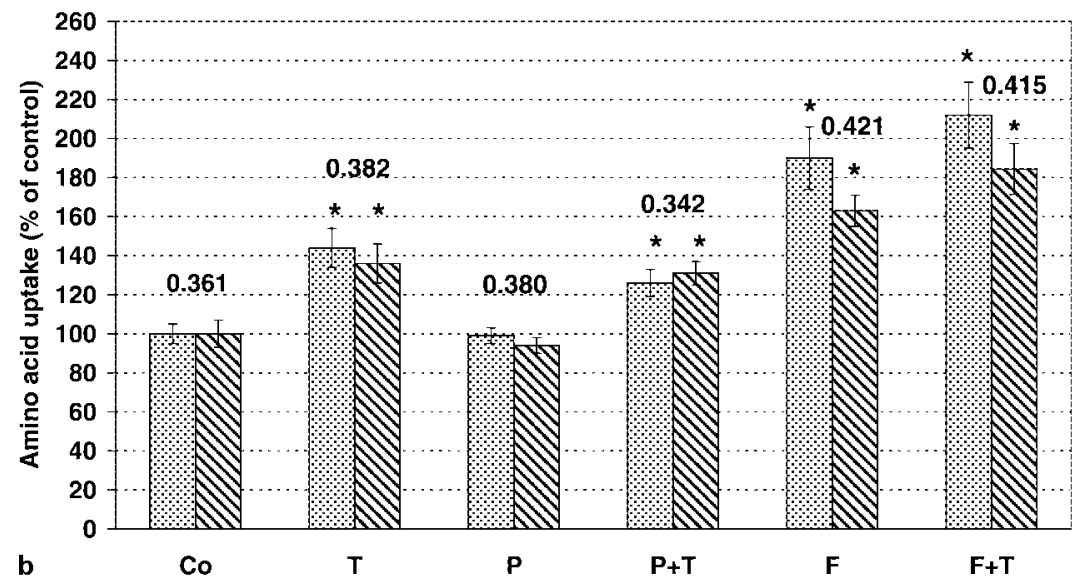

Mesangial cells

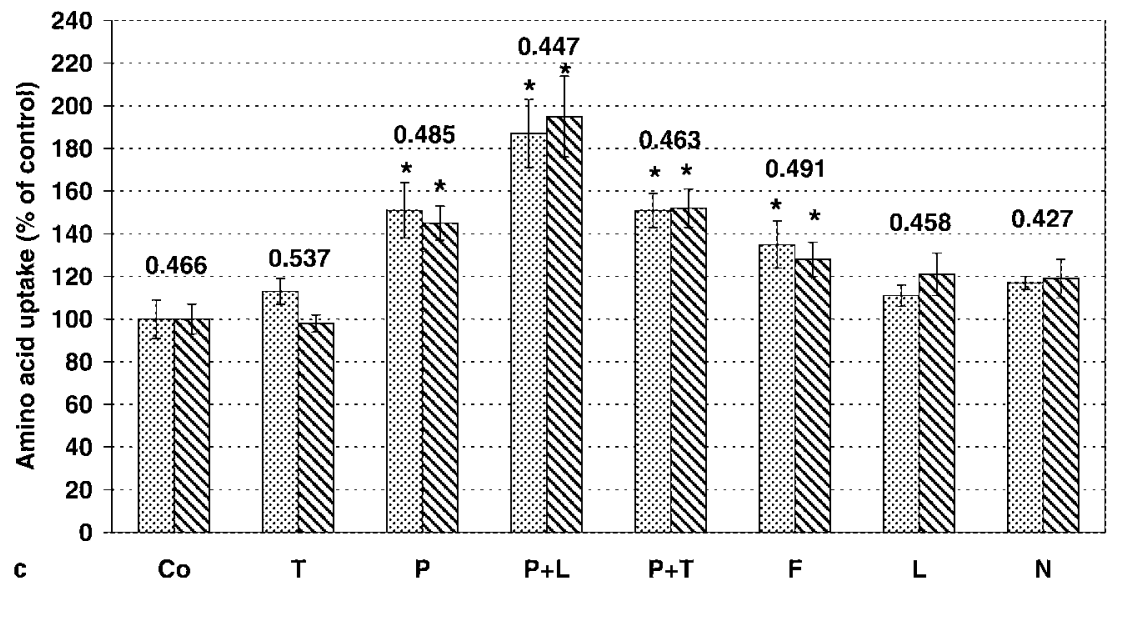

Nephron 2002;92:868-882 
Fig. 3. d Myofibroblasts. e Endothelial cells derived myofibroblast-like cells.
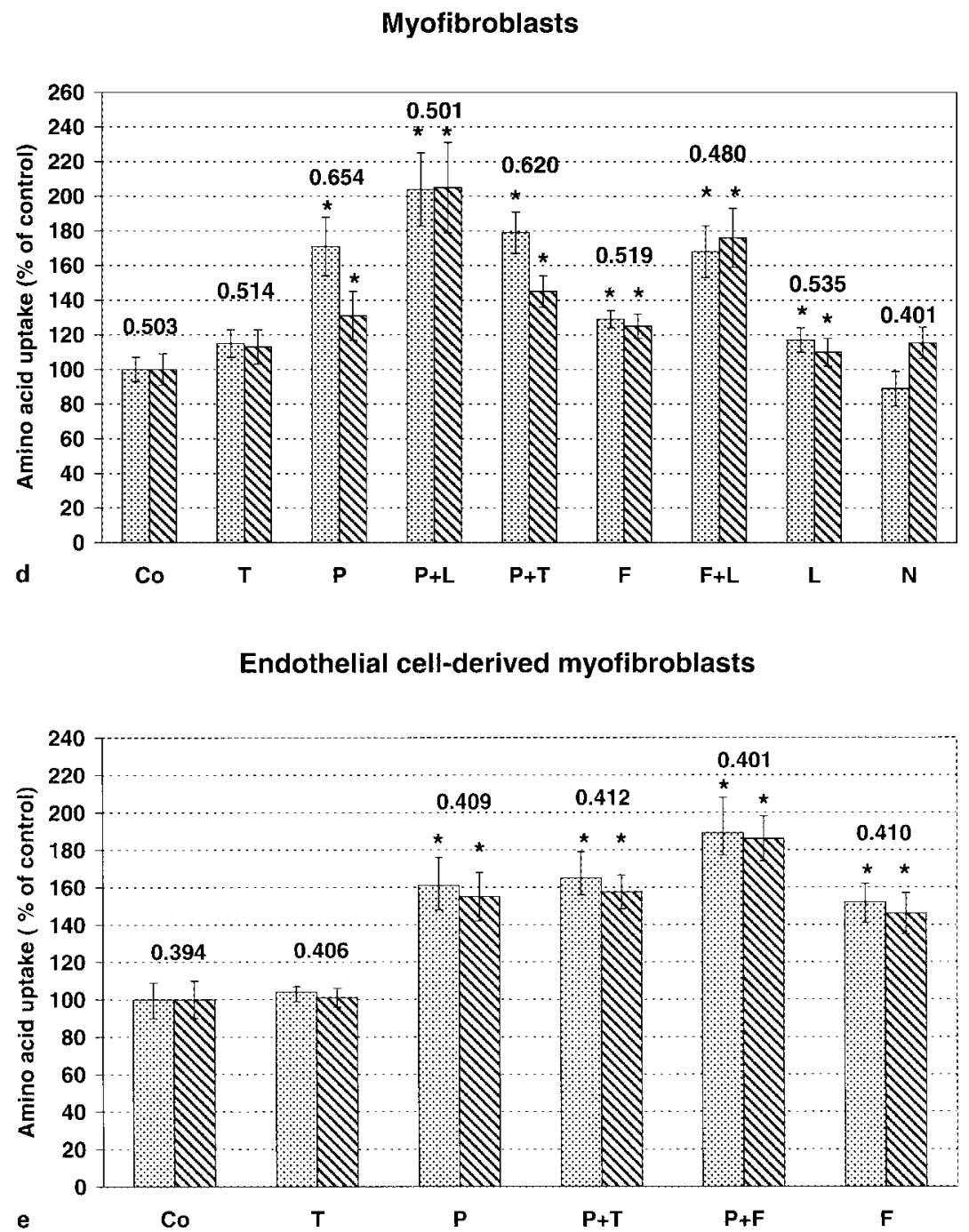

Co

$\mathbf{P}$

$\mathbf{P + T}$

$\mathbf{F}$

In table 2 the relative amounts of secreted proteins are given as a percentage of newly synthesized cellular proteins, determined by both Pro and Leu uptake. The means resulting from the two values (Pro and Leu uptake) show a secretion capacity of MC and MF that is about 4- to 6times higher than that of EDC and EPC, respectively. The slight differences between unstimulated and stimulated cells confirm the minimal influence of mediators on the composition of secreted proteins. The differences are cellspecific, and mediators had only a minor influence on the protein composition of cellular and secreted proteins.

\section{Discussion}

It has already been shown that there are no cytokines and growth factors that are fibrosis-specific $[1,3,5,8]$. Changes in cytokine concentrations during the development of fibrosis are similar to those seen in normal wound healing [20]. While repair processes in wound healing are self-limiting, these regulative mechanisms are disturbed in progressive fibrosis [9, 21, 22]. An understanding of the reasons for the progression of fibrosis remains, today, the main topic of current investigations. In addition to histological and immunohistochemical examinations of fibrot- 
Fig. 4. Secreted proteins into the culture medium. After incubation with ${ }^{3} \mathrm{H}-\mathrm{Pro}$ (gray columns) and ${ }^{3} \mathrm{H}-\mathrm{Leu}$ (hatched columns) the media from mesangial cell and myofibroblast cultures (see fig. $2 \mathrm{~d}$, e) were separated. After addition of BSA to aliquots of combined media from identical wells, the precipitated protein by $10 \%$ TCA was washed 3 fold using 5\% TCA, and the pellets were prepared to measuring radioactivity (see legend to fig. 1). $\mathrm{p}<0.05$ vs. controls. a Mesangial cells. b Myofibroblasts.

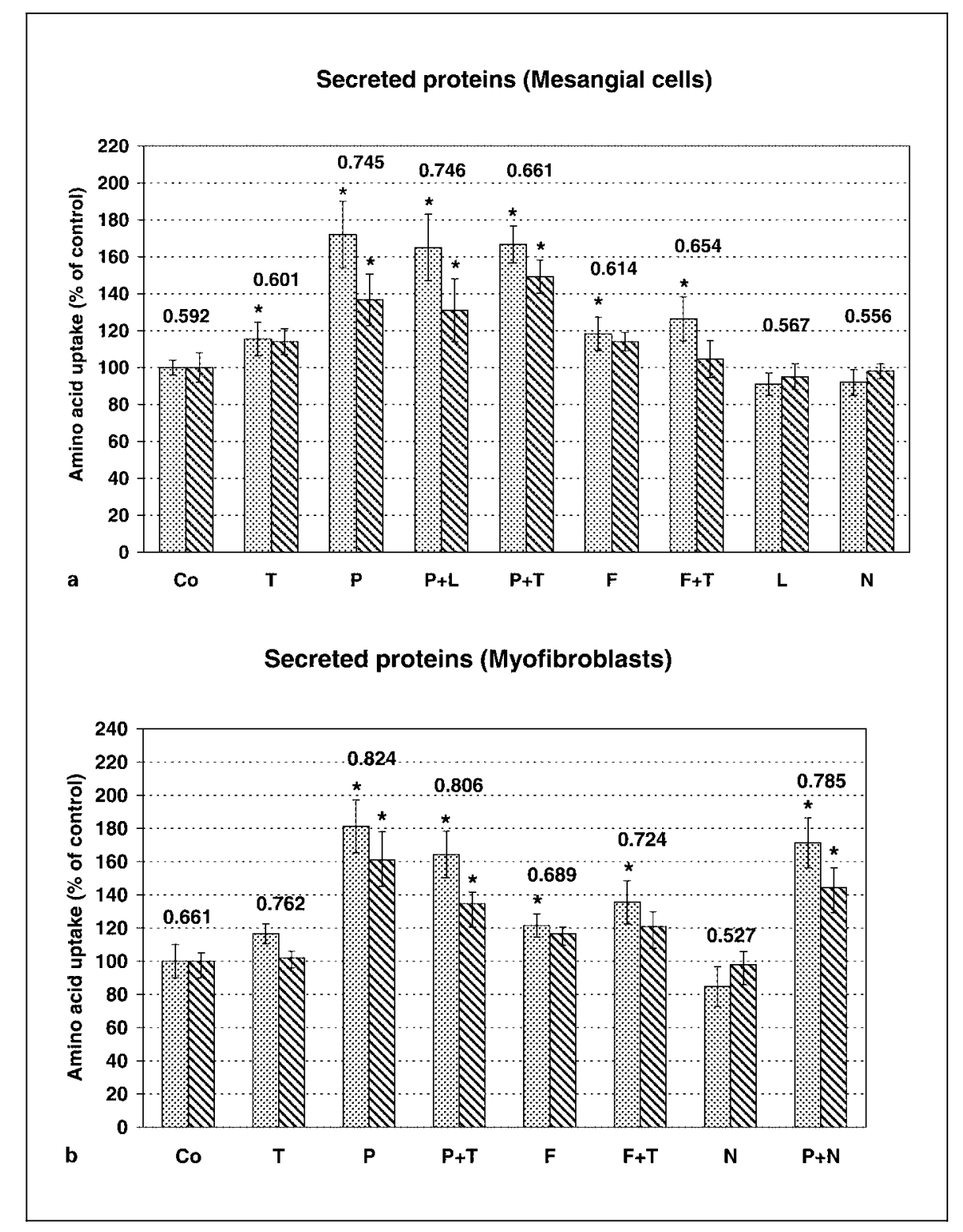

ic kidneys from laboratory animals, cell culture experiments may contribute to identifying the influence of individual or combined mediators on cell function. Suitable mediators for these experiments are primarily growth factors like PDGF-BB, bFGF, VEGF, TGF $\beta 1$, EGF, TNF $\alpha$, and some interleukins. As early as 1993, Fine et al. [6] concluded that ischemia, as a result of primary cell damage, will cause secondary damage to tubules and consequently expose antigens that lead to secondary inflammatory cell infiltrates in the affected areas. This concept of 'chronic hypoxia hypothesis' has been confirmed [23, 24], and finally these authors could verify that hypoxia per se may be a fibrogenic stimulus [25]. Compared to EPC, EDC seem to be more resistant to hypoxia as shown in the remnant kidney model [26]. It is suggested that damage of microvascular endothelial cells causes hypoxia, inflammation, and fibrogenic responses, leading to the obliteration of further capillaries, thereby setting up a vicious cycle [23, 24].

Our results revealed that endothelial cells are most sensitive to mediators which are secreted in inflammatory areas after kidney damage [3]. These mediators also stimulated the proliferation and protein secretion of ECMsynthesizing myofibroblast-like cells. In this respect, IL-4 
Table 2. De-novo synthesis of secreted proteins expressed as a percentage of synthesized cellular proteins ${ }^{1}$

\begin{tabular}{lcr}
\hline Cells & Unstimulated $^{2}$ & Stimulated $^{2}$ \\
\hline MC & 48.0 & $51.4 \pm 5.9(4)$ \\
MF & 46.2 & $43.6 \pm 5.1(4)$ \\
EDC & 10.7 & $9.9 \pm 1.2(4)$ \\
EPC & 7.6 & $7.6 \pm 0.4(4)$ \\
\hline
\end{tabular}

1 Measured by ${ }^{3} \mathrm{H}$-labelled amino acid incorporation.

2 Means \pm SD resulting from Pro and Leu incorporation in cell cultures, incubated with mediators (TGF, PDGF-BB, TGF + PDGF$\mathrm{BB}$ ) and from unstimulated control cultures; in the case of EPC, cells were cultured with EGF instead of PDGF-BB; number of undependent experiments, each performed in triplicate, is given in parentheses.

may play a special role. Besides IL-10 and IL-13, IL-4 is also considered to be an anti-inflammatory cytokine, which is able to inhibit the expression of inflammatory mediators and macrophage functions [27]. IL-4 is a pleiotropic cytokine that has multiple cell-type specific activities [28, 29], and has also been proposed as playing a role in glomerulonephritis [30]. Pretreatment with IL-4 decreased crescent formation and improved renal function [31, 32]. Postlethwaite et al. [33] and Salmon-Ehr et al. [34] demonstrated that IL-4 is able to stimulate the synthesis of ECM compounds by fibroblasts (collagens type I, III and fibronectin) in vivo. According to Sempowski et al. [35] elevated levels of IL-4 may lead to the development of fibrosis by enhancing fibroblast subset proliferation and collagen synthesis. Our results represent IL-4 as a cytokine without any stimulating effects on the proliferation of bovine cells (MC, MF, TEC). In the presence of the growth factors PDGF-BB and bFGF, however, IL-4 acts in a co-stimulating manner. The special role of PDGF-BB in progressive fibrotic disease has been previously discussed [36]. Its causative role in renal scarring could be shown by the inhibition of the PDGF-BB effect in animal models of RIF and glomerulonephritis [37]. The assumption that only pro-inflammatory cytokines secreted by Th1-lymphocytes promote fibrosis should be amended so that cytokines liberated by Th2-lymphocytes are likewise implicated in this process [38].

The question concerning the origin of ECM-synthesizing cells in RIF still remains open. Different sources have been discussed: constitutive interstitial fibroblasts could be transformed into metabolically active myofibroblasts; smooth muscle cells from the adventitia of renal vessels could migrate as myofibroblasts into the damaged interstitium [39, 40]; and finally cells like EPC and microvascular EDC are able to transdifferentiate into mesenchymal cells [11, 12, 41, 42]. In our experiments bovine EDC and GEDC transdifferentiated into myofibroblasts under cell culture conditions in the presence of TNF $\alpha$ or the combination of TNF $\alpha$ with other growth factors. Apart from the in vivo transdifferentiation of tubular EPC into MFLC as discussed by Strutz et al. [43] and convincingly demonstrated by Fan et al. [12], EDC can also transdifferentiate into MFLC in the presence of a suitable mediator cocktail in inflamed tissue. In view of the high sensitivity of EDC to TNF $\alpha$ and other cell growth inhibiting mediators, we assume that the transdifferentiation of EDC may be involved in RIF. In histological examinations of kidney slices from patients with RIF, Bohle et al. [44] confirmed a decrease in tubulointerstitial capillaries. So far, it is not known whether EDC from obstructed capillaries are completely destroyed by apoptosis or if microvascular EDC transdifferentiate into MFLC that take part in the ECM-synthesis. In organs other than kidney, an endothelial cell-myofibroblast transdifferentiation has already been established [45, 46]. Madri et al. [47] described changes of EDC near the site of injury and the role of dysfunctional endothelium in the pathogenesis of atherosclerosis. Moreover, they proved that cultured EDC may synthesize $\alpha$ SMA in the presence of TGF $\beta$ [47]. In addition to the embryonic EDC transdifferentiation into mesenchymal cells described by DeRuiter [48] and Nakayima et al. [46], Baranek et al. [39] assumed that MFLC may originate from the vascular endothelium in inflammatory disease.

The presence of TNF $\alpha$ seems to be essential for the transdifferentiation of EDC into MFLC. TNF $\alpha$ and IL- $1 \beta$ are cytokines that mediate the onset of fibrosis and maintain inflammation in the damaged areas [49]. TNFa exerts a variety of biological effects on glomerular MC and EPC and is believed to contribute to the severity of renal lesions [50, 51]. Sato et al. [52] described the specific toxicity of TNFa to EDC. It may be assumed that the transdifferentiation of EDC into TEC in damaged areas could protect these cells from apoptosis or necrosis. Moreover, these cells can be used for ECM-synthesis in repair processes.

TGF $\beta 1$ is considered to be a major fibrogenic molecule in many experimental and human diseases $[18,19]$. In our cell culture experiments, only a minor stimulating effect of TGF $\beta 1$ on protein secretion was seen, but rather the dependence of protein secretion on the growth behavior of cells. Under cell culture conditions resting cells do not 
secrete significantly more proteins than proliferating cells. The comparison of the Pro/Leu ratio between cellular and secreted proteins can provide information only on the relative changes of the collagen content. Yet, this method is sufficient to detect different effects of mediators on ECM synthesis. The relatively low amount of proteins secreted by EDC and EPC as compared to MFLC suggest that EPC and EDC may contribute to fibrogenesis only marginally whereas the mainly ECM-synthesizing cells (MC, MF, and TEC) can be stimulated strongly by growth factors and cytokines. We compared MC and EDC with MF obtained as outgrowths from arteries. These cells may originate from vascular smooth muscle cells (VSMC) having lost their original characteristics.

As found by Alpers et al. [53], the expression of PDGF $\beta$-receptors seems to characterize MFLC more than smooth muscle cells. In our experiments, the proliferation of MF was highly stimulated by PDGF-BB, suggesting that VSMC transdifferentiate into MF under pro- longed cell culture conditions. Fine and co-workers [24, 25, 54] and Yamamoto [19] also emphasize the particular importance of the impaired microvasculature during progressive RIF. We assume that damaged EPC are the primary reason for inflammation, and EDC damage plays a significant role. This takes into account that, for the focal development of fibrosis, primarily damaged areas must exceed a certain threshold to cause progressive fibrosis. The ongoing presence of stimulated ECM-synthesizing cells of different origin in damaged renal tissue is assumed to be decisive for the disease and should be the subject of further investigation.

\section{Acknowledgements}

This work was supported by a grant from the BMBF (Bundesministerium für Bildung und Forschung) No. 01ZZ9602/7.

\section{References}

1 Kunico GS, Neilson EG, Haverty T: Mechanisms of tubulointerstitial fibrosis. Kidney Int 1991;39:550-556.

2 Müller GA, Schettler V, Müller CA, Strutz F: Prevention of progression of renal fibrosis: How far are we? Kidney Int 1996;49(suppl 54):S75-S82.

3 Strutz F, Neilson EG: The role of lymphocytes in the progression of interstitial disease. Kidney Int 1994;45(suppl 54):S106-S110.

4 Nath KA: The tubulointerstitium in progressive renal disease. Kidney Int 1998;54:992994.

5 Kovacs EJ: Fibrogenetic cytokines: The role of immune mediators in the development of scar tissue. Immunol Today 1991;12:17-23.

6 Fine LG, Ong ACM, Norman JT: Mechanisms of tubulo-interstitial injury in progressive renal diseases. Eur J Clin Invest 1993;23:259-265.

7 Hogaboam CM, Steinhauser ML, Chensue SW, Kunkel SL: Novel roles for chemokines and fibroblasts in interstitial fibrosis. Kidney Int 1998;54:2152-2156.

8 Wardle EN: Renal collagen synthesis and its control. Nephron 1999;83:106-110.

9 Sappino A, Schürch W, Galbiani G: Differentiation repertoire of fibroblastic cells: Expression of phenotypic modulations. Lab Invest 1990; 63:144-161.

10 Alpers CE, Hudkins KL, Floege J, Johnson RJ: Human renal cortical interstitial cells with some features of smooth muscle cells participate in tubulointerstitial and crescentic glomerular injury. J Am Soc Nephrol 1994;5:201210 .
11 Okada H, Inoue T, Suzuki H, Strutz F, Neilson EG: Epithelial-mesenchymal transformation of renal tubular epithelial cells in vitro and in vivo. Nephrol Dial Transplant 2000;15(suppl 6):44-46.

12 Fan JM, Ng YY, Hill PA, Nikolic-Paterson DJ, $\mathrm{Mu} \mathrm{W}$, Atkins RC, Lan HY: Transforming growth factor- $\beta$ regulates tubular epithelialmyofibroblast transdifferentiation in vitro. Kidney Int 1999;56:1455-1467.

13 Johnson RJ, Floege J, Couser WG, Alpers CE: Role of platelet-derived growth factor in glomerular disease. J Am Soc Nephrol 1993;4: 119-128.

14 Ludewig D, Kosmehl H, Sommer M, Böhmer FD, Stein G: PDGF receptor kinase blocker AG 1295 attenuates interstitial fibrosis in rat kidney after unilateral ureteral obstruction. Cell Tissue Res 2000;299:97-103.

15 Sommer M, Schaller R, Fünfstück R, Bohle A, Böhmer FD, Müller GA, Stein G: Abnormal growth and clonal proliferation of fibroblats in an animal model of unilateral ureteral obstruction. Nephron 1999;82:39-50.

16 Elias JA: Tumor necrosis factor interacts with interleukin-1 and interferons to inhibit fibroblast proliferation via fibroblast prostaglandindependent and -independent mechanisms. Am Rev Respir Dis 11988;38:652-658.

17 Stratford MRL, Watfa RR, Murray C, Martin SG: Determination of collagen and protein turnover by high-performance liquid chromatography. J Chromatog 1990;529:383-395.
18 Border WA, Okuda S, Languino LR, Sporn MB, Ruoslathi E: Suppression of experimental glomerulonephritis by antiserum against transforming growth factor- $\beta 1$. Nature 1990;346: 371-374.

19 Yamamoto T, Noble NA, Miller DE, Border WA: Sustained expression of TGF- $\beta 1$ underlies development of progressive kidney fibrosis. Kidney Int 1994;45:916-927.

20 Clark RAF: Wound repair. Cur Opin Cell Biol 1989;1:1000-1008.

21 Gabbiani G: The biology of the myofibroblast Kidney Int 1992;41:530-532.

22 Darby I, Skalli O, Gabbiani G: Smooth muscle actin is transiently expressed by myofibroblasts during experimental wound healing. Lab Invest 1990;63:21-29.

23 Fine LG, Ong ACM, Norman JT: Mechanisms of tubulo-interstitial injury in progressive renal diseases. Eur J Clin Invest 1993;23:259-265.

24 Fine LG, Bandyopadhay D, Norman JT: Is there a common mechanism for the progression of different types of renal diseases other than proteinuria? Towards the unifying theme of chronic hypoxia. Kidney Int 2000;57(suppl 75):S22-S26.

25 Norman JT, Clark JM, Garcia PL: Hypoxia promotes fibrogenesis in human renal fibroblasts. Kidney Int 2000;58:2351-2366.

26 Kirkland G; Paizis K; Wu LL; Katerelos M; Power DA: Heparin-binding EGF-like growth factor mRNA is upregulated in the peri-infarct region of the remnant kidney model: In vitro evidence suggests a regulatory role in myofibroblast transformation. J Am Soc Nephrol 1998; 9:1464-1473. 
27 Romagnani S: Th1/Th2 cells. Inflamm Bowel Dis 1999;5:285-294.

28 Nakazato Y, Hayashida T, Kanno Y, Sasamura H, Okada H, Suzuki H, Saruta T: Interleukin (IL)-1 and IL-4 synergistically stimulate NFIL6 activity and IL-6 production in human mesangial cells. Kidney Int 1998;54:71-79.

29 Taki H, Sugiyama E, Kuroda A, Mino T, Kobayashi M: Interleukin-4 inhibits interleukin11 production by rheumatoid synovial cells. Rheumatology 2000;39:728-731.

30 Knerer B, Formanek M, Temmel A, Martinek H, Schickinger B. Kornfehl J: The role of fibroblasts from oropharyngeal mucosa in producing proinflammatory and mitogenic cytokines without prior stimulation. Eur Arch Otorhinolaryngol 1999;256:266-270.

31 Van den Berg IG, Aten J, Chand A, Claessen N, Dijkind L, Wijdenes J, Lakkis FG, Weening JJ: Interleukin-4 and interleukin 13 act on glomerular visceral epithelial cells. J Am Soc Nephrol 2000;11:413-422.

32 Tipping PG, Kitching AR, Huang XR, Mutch DA, Holdsworth SR: Immune modulation with interleukin- 4 and interleukin-10 prevents crescent formation and glomerular injury in experimental glomerulonephritis. Eur J Immunol 1997;27:530-537.

33 Postlethwaite AE, Holness MA, Katai H, Raghaw R: Human fibroblasts synthesize elevated levels of extracellular matrix proteins in response to interleukin-4. J Clin Invest 1992;90: 1479-1485.

34 Salmon-Ehr V, Gillery P, Kalis B, Bancherau J, Maquart FX: Interleukin-4: From B-lymphocyte to fibroblast. Pathol Biol Paris 1996;42: 262-268.

35 Sempowski GD, Beckmann MP, Derdak S, Phipps RP: Subsets of murine lung fibroblasts express membrane bound and soluble IL-4 receptors. J Immunol 1994; 152:3606-3613.

36 Johnson RJ, Floege J, Couser WG, Alpers CE: Role of platelet-derived growth factor in glomerular disease. J Am Soc Nephrol 1993;4: 119-128.
37 Johnson RJ, Raines E, FloegeJ, Yoshimura A, Pritzzl P, Alpers CE, Ross R: Inhibition of mesangial cell proliferation and matrix expansion in glomerulonephritis in the rat by antibody to platelet derived growth factor. J Exp Med 1992;175:1413-1416.

38 Lakkis FG, Baddoura FK, Cruet EN, Parekh KR, Fukunaga M, Munger KA: Anti-inflammatory lymphokine mRNA expression in antibody-induced glomerulonephritis. Kidney Int 1996;49:117-126.

39 Beranek JT, Masseyeff R: Hyperplastic capillaries and their possible involvement in the pathogenesis of fibrosis. Histopathology 1986; 10:543-551.

40 Baradin KA, Desmeth VJ: Ultrastructural observations on sinusoidal endothelial cells in chronic active hepatitis. Histopathology 1992; 9:171-181.

41 Hay ED: An overview of epithelio-mesenchymal transformation. Acta Anat 1995;154:820.

42 Yang J, Liu Y: Dissection and key events in intubular epithelial to myofibroblst transition and its implication in renal interstitial fibrosis. Am J Pathol 2001;159:1465-1475.

43 Strutz F: The fibroblast - a (trans-)differentiated cell? Nephrol Dial Transplant 1995;10: 1504-1506.

44 Bohle A, Gise HV, Mackensen-Haen S, StarJacob B: The obliteration of the postglomerular capillaries and its influence upon the function of both glomeruli and tubuli. Klin Wochenschr 1981;59:1043-1051.

45 Petroll WM, Barry-Lane PA, Cavanagh HD, Jester JV: Z0-1 reorganisation and myofibroblast transformation of corneal endothelial cells after freeze injury in the cat. Exp Eye Res 1997;64:257-267.
46 Nakayima Y, Mironov V, Yamagishi T, Nakamura H, Markwald RR: Expression of smooth muscle alpha-actin in mesenchymal cells during formation of avian endocardial cushion tissue: A role for transforming growth factor beta 3. Dev Dyn 1997;209:296-309.

47 Madri JA, Bell L, Marx M, Merwin JR, Basson C, Prinz Ch: Effects of soluble factors and extracellular matrix components on vascular cell behavior in vitro and in vivo: Models of de-endothelization and repair. $\mathrm{J}$ Cell Biochem 1991;45:123-130.

48 DeRuiter MC, Poelmann RE, VanMunsteren JC, Mironov V, Markwald RR, Gittenbergerde-Groot AC: Embryonic endothelial cell transdifferentiale into mesenchymal cells expressing smooth muscle actins in vivo and in vitro. Circ Res 1997;80:444-451.

49 Niemir ZI, Ondracek M, Dworacki G, Stein H, Waldherr R, Ritz E, Otto HF: In situ upregulation of IL-10 reflects the activity of human glomerulonephritides. Am J Kidney Diseases 1998;32:80-92.

50 Noronha IL, Krüger C, Andrassy K, Ritz E, Waldherr R: In situ expression of TNF- $\alpha$, IL- $1 \beta$ and IL-2 in ANCA-positive glomerulonephritis. Kidney Int 1993;43:682-692.

51 Bosswell, Yui MA, Burt DW, Kelly VE: Increased tumor necrosis factor and IL- $1 \beta$ gene expression in kidney of mice with lupus nephritis. J Immunol 1988;141:3050-3054.

52 Sato N, Goto T, Haranaka K, Satomi N, Nariuchi H, Mano-Hirano Y, Sawasaki Y: Action of tumor necrosis factor on cultured vascular endothelial cells: Morphologic modulation, growth inhibition and cytotoxicity. J Nat Cancer Inst 1986;76:1113-1121.

53 Alpers CE, Seifert RA, Hudkin KL, Jahnson RJ, Bowen-Pope DF: PDGF-receptor localizes to mesangial, parietal epithelial, and interstitial cells in human and primate kidney. Kidney Int 1993;43:286-294.

54 Orphanides C, Fine LG, Norman JT: Hypoxia stimulates proximal tubular cell matrix production via a TGF- $\beta 1$ independent mechanism. Kidney Int 1997;52:637-647.

\section{Commentary \\ Renal Fibrosis: Origin and Potential of Myofibroblasts}

\section{E.N. Wardle}

Oxford, UK

Fibrosis arises in the kidneys when there has been damage to the glomeruli and tubules, and so there is atrophy of the normal architecture, and fibroblasts that produce new extracellular matrix expand the interstitial space. There are many causes of tubulo-interstitial fibrosis (TIF), ranging from the effects of hypertension, glomerulonephritides and pyelonephritis to causes of heavy pro- teinuria, and any process that incites proximal tubules to produce pro-inflammatory mediators as occurs in chronic rejection. From the time of injury both interstitial cells and proximal tubules are activated and myofibroblasts appear. Myofibroblasts, defined by their expression of $\alpha$ SMA (smooth muscle actin) often correlate with the degree of renal impairment and histological damage [1]. 
They play a key role in the development of glomerulosclerosis and interstitial fibrosis [2]. Table 1 summarises the processes that trigger fibrosis.

Fibroblasts are not homogenous [14] for they include functionally different interstitial cells called fibroblastlike cells (FbLCs). In cortex [15] and outer medulla [16] or kidneys there are pericytes that become interstitial fibroblasts, and there are unique interstitial fibroblasts in the inner medulla that contain lipid droplets and react with the lectin Bandeira simplicifolia-1 (BSL-1). Shortly, I will gather the evidence that myofibroblasts (MF) arise from tubular epithelial cells [17] and we know that they are formed from mesangial cells [18], and in their current article Sommer et al. [19] suggest that they also arise from endothelial cells that are involved in inflammation. Granulation tissue MFs of skin, since they are accessible, were soon shown to produce muscle related phenotypic markers like $\alpha$-SMA, vimentin (Vim), desmin and myosin heavy chain. Fibroblasts in murine kidneys stain with fibroblasts specific protein FSP-1, and the mesenchymal markers $\alpha \mathrm{ASM}$ and Vim. In normal kidneys Vim+ fibroblast like cells occur as in dermis. Yet is this the case in diseased kidneys? Okada et al. [20] looked at Goodpasture syndrome in rats and found $\alpha$-SMA+ FbLCs negative for Vim and negative for TGF $\beta$, and other fibroblasts that were negative for $\alpha$-SMA and for Vim that were producing $\alpha 1$ (I)procollagen! So they have reminded us that the exact contribution of $\alpha$-SMA+ FbCLs to fibrogenesis still requires appraisal [21]. In their study, SMA-negative fibroblasts were producing type I collagen. The MF is a motile cell and further gene changes may be required before collagen is synthesised. That renal tubular epithelial cells can transdifferentiate into MFs expressing FSP1, aSMA and Vim has been proposed for some time and the evidence is persuasive [22-24]. (i) There is loss of epithelial cell adhesion, and indeed TGF $\beta$ suppresses expression of E-cadherins. (ii) The tubular cells express $\alpha$-SMA and undergo actin reorganisation. (iii) There is disruption of tubular basement membrane. (iv) There is cell migration and invasion of the interstitium by MFs. MFs are morphologically intermediate between fibroblasts and smooth muscle cells and they have the ability to contract. Moreover, they form fibronectin and collagens I and III to add to the extracellular matrix.

Epithelial-mesenchymal transformation (EMT) is produced most efficaciously by TGF $\beta$ acting with epidermal growth factor (EGF) [22]. PDGF-BB administered to rats induces a dose dependent proliferation of tubulointerstitial cells associated with expression of $\alpha$-SMA [26]. Therefore, PDGF-BB actin along with TGF $\beta$ may be the usual
Table 1. Processes leading to tubulo-interstitial fibrosis

1 Hydraulic pressure damaging glomeruli and postglomerular capillaries with ischaemia and hypoxia [3] affecting the tubules Along with hypertension, angiotensin II [4] has a key role

2 Leakage of proteins into the tubules [5]

That means exposure of the tubules internally to arachidonic acid products [6], to lysophosphatidic acid [7] and complement components [8]

3 Inflammatory cells in nonimmune [9] and immune reactions, producing oxidative stress [10], exacerbated by oxidise LDL [11] and available cholesterol

Calcium is often deposited in tubular cells

4 Liberation of metalloproteinases [12] that damage tubular basement membranes

Mast cells producing [13] tryptase

cause of EMT. PDGF-BB receptors are plentiful on MFs and TGF $\beta$ receptors are upregulated on all cells in areas of renal damage. Connective tissue growth factor is strongly expressed in resident cells of the kidney at sites of tubulointerstitial damage but not by monocyte-macrophages. CTGF helps cell migration and formation of collagen and fibronectin, but it does not aid proliferation of cells and it does not induce MFs [27]. The products of Th-2 lymphocytes like interleukin-4 (IL-4) and the chemokine monocyte-chemotactic protein MCP-1 have an established place in pulmonary fibroses [28]. Therefore, it has been suspected that although IL-4 administration may reduce proteinuria experimentally, it could go on to induce renal fibrosis. So it is interesting that Sommer et al. [19] find that IL-4 costimulates PDGF-BB or bFGF mediated proliferation of mesangial cells and MFs. Also interesting is their demonstration that PDGF-BB or bFGF support $\mathrm{TNF} \alpha$ mediated transdifferentiation of endothelial cells into MFs [19].

What can be done about pulmonary fibrosis [29] could impart some ideas to those studying kidneys, for example the use of pirfenidone. Nephrology has yielded some surprises too, for now we are contemplating the use of hepatocyte growth factor (HGF) to offset renal fibrosis [30-31] and relaxin could have something to offer [32]. For those who prefer drugs that are available, there is the news that fluvastatin suppresses interstitial expansion and MF formation in obstructed kidneys of mice [33]. That is supported by evidence from Melbourne that lovastatin can decrease MF proliferation and growth. It also decreases collagen synthesis [34]. The theoretical background to such wondrous effects has recently been reviewed [35], but we shall have to look out for side effects. 


\section{References}

1 Yang N, Wu LL, Nikolic-Paterson DJ, NgY-Y, Yang W-C, Mu W, Gilbert RE, Cooper ME, Atkins RC, Lan HY: Local macrophage and myofibroblast proliferation in progressive renal injury in the rat remnant kidney. Nephrol Dial Transplant 1998;13:1967-1974.

2 Hewitson TD, Becker GJ: Myofibroblast involvement in renal interstitial fibrosis. Nephrology 1996;2:229-234.

3 Norman JT, Clark JM, Garcia PL: Hypoxia promotes fibrogenesis in human renal fibroblasts. Kidney Int 2000;58:2351-2366.

4 Wolf G: Angiotensin II as a mediator of tubulointerstitial injury. Nephrol Dial Transplant 2000;15(suppl 6):61-63.

5 Ruggenenti P, Remuzzi G: The role of protein traffic in the progression of renal diseases. Ann Rev Med 2000;51:315-327.

6 Alexander LD, Cui X-L, Falck JR, Douglas JG: Arachidonic acid directly activates members of the MAP kinase superfamily in rabbit proximal tubule cells. Kidney Int 2001;59:2039-2053.

7 Iglesias J, Levine JS: Albuminuria and renal injury. Nephrol Dial Transplant 2001;16:215-218.

8 Matsuo S, Morita Y, Mizuno M, Nisikawa K, Yuzawa Y: The role of complement in the progression of renal fibrosis: A clinical study. Nephrol Dial Transplant 2000;15(suppl 6):53-54.

9 Rodriguez-Iturbe B, Pons H, Herrera-Acosta J, Johnson RJ: Role of immunocompetent cells in nonimmune renal diseases. Kidney Int 2001;59: $1626-1640$

10 Moriyama T, Kawada N, Nagatoya K, Horio M, Imai E, Hori M: Oxidative stress in tubulointerstitial injury: Therapeutic potential of antioxidants towards interstitial fibrosis. Nephrol Dial Transpl 2000;15(suppl 6):4749.

11 Leonarduzzi G, Arkan MC, Basaga H, Chiarpotto R, Sevanian A, Poli G: Lipid oxidation products in cell signaling. Free Radic Biol Med 2000;28: 1370-1378.

12 Opdenakker G, Evandensteen P, Van Damme J, Gelatinase B: A tuner and amplifier of immune functions. Trends Immunol 2001;22:571-579.

13 El-Koraie AF, Baddour NM, Adam AG, El Kashef EH, E1 Nahas AM: Role of stem cell factor and mast cells in the progression of chronic glomerulonephritides. Kidney Int 2001;60:167-172.

14 Schmitt-Graeff A, Desmoulière A, Gabbiani G: Heterogeneity of myofibroblast phenotypic features. Virchow Arch 1994;425:3-24.

15 Alpers CE, Pichler R, Johnson RJ: Phenotypic features of cortical interstitial cells important for fibrosis. Kidney Int 1996;49:28S-31S.

16 Rodemann HP, Muller GA, Knecht A, Norman JT, Fine LG: Fibroblasts of rabbit kidney in culture. I. Characterisation and identification of cell specific markers. Am J Physiol 1991;261:F283-291.

17 Ng Y-Y, Huang T-P, Yang W-C, Chen Z-P, Yang A-H, Mu W, NikolicPaterson DJ, Atkins RC, Lan HY: Tubular epithelial-myofibroblast transdifferentiation in progressive tubulointerstitial fibrosis in $5 / 6$ nephrectomized rats. Kidney Int 1998;54:864-876.

18 Zhang G, Moorhead OJ, El Nahas AM: Myofibroblasts and the progression of experimental glomerulonephritis. Exp Nephrol 1995;3:308-318.

19 Sommer M, Eismann U, Gerth J, Stein G: Interleukin 4 costimulates the PDGF-BB and bFGF mediated proliferation of mesangial cells and fibroblasts. Nephron 2002, in press.
20 Okada H, Inoue T, Kanno Y, Kobayashi T, Ban S, Kalluri R, Suzuki H: Renal fibroblast-like cells in Goodpasture syndrome rats. Kidney Int 2001; 60:597-606

21 Powell DW, Mifflin RC, Valentich JD, Crowe SE, Saada JL, West AB Myofibroblasts I. Paracrine cells important in health and disease. Am J Physiol 1999;277:C1-C19.

22 Okada H, Inoue T, Suzuki H, Strutz F, Neilson EG: Epithelial-mesenchymal transformation of renal tubular epithelial cells. Nephrol Dial Transplant 2000;15(suppl 6):44-46.

23 Jinde K, Nikolic-Paterson DJ, Huang XR, Sakai H, Kurokawa K, Atkins RC, Lan HY: Tubular phenotypic change in progressive tubulointerstitial fibrosis in human glomerulonephritis. Am J Kid Dis 2001;38:761-769.

24 Yang J, Liu Y: Dissection of key events in tubular epithelial to myofibroblast transition and its implications in renal interstitial fibrosis. Am J Pathol 2001;159:1465-1475.

25 Fan JM, Ng YY, Hill PA, Nikolic-Paterson DJ, Mu W, Atkins RC, Lan YH: Myofibroblast transdifferentiation in vitro. Kidney Int 1999;56:14551467.

26 Tang WW, Ulich TR, Lacey DL, Hill DC, Qi M, Kaufman SA, Van GY, Tarpley JE, Yee JS: Platelet derived growth factor-BB induces renal interstitial myofibroblast formation and tubulointerstitial fibrosis. Am J Pathol 1996;148:1169-1180.

27 Blom IE, van Dijk AJ, Wieten L, Duran K, Ito Y, Kleij L, deNichilo M, Rabelink TJ, Weening JJ; Aten J, Goldschmeding R: In vitro evidence for differential involvement of CTGF, TGF $\beta$ and PDGF-BB in mesangial response to injury. Nephrol Dial Transplant 2001;16:1139-1148.

28 Sime PJ, O'Reilly KMA: Fibrosis of the lung and other tissues: New concepts in pathogenesis and treatment. Clin Immunol 2001;99:308-319.

29 Gross TJ, Hunninghake GW: Idiopathic pulmonary fibrosis. N Engl J Med 2001;345:517-525.

30 Mizuno S, Matsumoto K, Nakamura T: Hepatocyte growth factor suppresses interstitial fibrosis in a mouse model of obstructive nephropathy. Kidney Int 2001;59:1304-1314.

31 Matsumoto K, Nakamura T: Hepatocyte growth factor: Renotropic role and potential therapeutics for renal diseases. Kid Int 2001;59:2023-2038.

32 Garber SL, Microchnik Y, Brecklin CS, Unemori EN, Singh AK, Slobodkoy L, Grove BH, Arruda JAL, Dunea G: Relaxin decreases renal interstitial fibrosis and slows progression of renal disease. Kidney Int 2001;59: 876-882.

33 Moriyama T, Kawada N, Nagatoya K, Takeji M, Horio M, Ando A, Imai E, Hori M: Fluvastatin suppresses oxidative stress and fibrosis in the interstitium of mouse kidneys with unilateral ureteral obstruction. Kidney Int 2001;59:2095-2103.

34 Kelynack KJ, Hewitson TD, Martic M, McTaggart S, Becker GJ: Lovastatin downregulates renal myofibroblast function in vitro. Nephron 2002, in press.

35 Massy ZA, Guijarro C: Statins: Beyond cholesterol lowering. Nephrol Dial Transplant 2001;16:1738-1741. 